COVER ESSAY

\title{
Philip Morris changes its name, but not its harmful practices
}

\section{L Myers}

Tobacco Control 2002;11:169-170

\begin{abstract}
After spending more than $\$ 250$ million on an advertising campaign to improve its name and reputation, Philip Morris has abruptly shifted course and decided instead to change its corporate name-to The Altria Group, Inc.
\end{abstract}
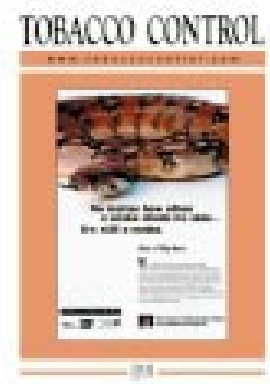

Correspondence to: Matthew L Myers, National Center for Tobacco-Free Kids, 1707 Lower Street NW, Suite 800 , Washington, DC 20036, USA; mmyers@ tobaccofreekids.org
W hy has Philip Morris changed its name to The Altria Group? The answer is obvious. The public isn't buying Philip Morris's image makeover. In January, Philip Morris ranked second to last, just above tyremaker Bridgestone/Firestone of exploding tyre notoriety, in a US survey of corporate reputations conducted by The Reputation Institute and Harris Interactive. ${ }^{1}$

It should surprise no one that the company's image remained low. While spending millions to tell us about the charitable efforts of the "People of Philip Morris", the people who run the company are up to the same old behaviour. Philip Morris's name change represents a classic public relations gesture-to create the illusion of change and sway the elected officials and jurors who can bring about the real change in their harmful practices, even while the company continues business as usual.

\section{STILL ADDICTING CHILDREN}

Philip Morris claims it does not want kids to smoke-actually it has been claiming this for 40 years-but the facts continue to tell a very different story. As part of the 1998 state tobacco settlement, Philip Morris and the other tobacco companies promised not to "take any action, directly or indirectly, to target youth". How did the tobacco companies respond? They promptly increased their marketing expenditures to record levels, much of it in ways even more effective at attracting children.

In the two years after the settlement, the cigarette manufacturers increased their marketing expenditures by $42 \%$, reaching $\$ 9.57$ billion$\$ 26.2$ million a day-in 2000, according to the most recent annual report on cigarette marketing by the Federal Trade Commission (FTC). ${ }^{2}$

Initial attention after the settlement focused on increased cigarette advertising in youth oriented magazines, those with at least 15\% of their readership or two million readers under age 18. Several studies found that the leading cigarette brands all increased their advertising in youth oriented magazines after the settlement, reaching most youth at saturation levels of exposure. $^{3-5}$ Philip Morris likes to remind us that it no longer advertises in such magazines, but it fails to mention that it stopped only after being caught red-handed.

Moreover, magazine advertising has been but a small part of the overall cigarette marketing budget, and Philip Morris is dominant in a much larger venue that may be even more effective at reaching children-point of sale marketing at the retail store level.

According to the FTC, retail store cigarette marketing increased by $65 \%$ since 1998 to a total of $\$ 7.8$ billion in 2000 , which accounts for $81 \%$ of all cigarette marketing. This is a highly effective way of reaching children as studies have shown that $75 \%$ of adolescents shop at convenience stores at least once a week, and they are more likely than adults to be influenced by convenience store promotions. ${ }^{67}$ Specific increases include payments to retailers for prime shelf space that make cigarettes more visible to kids, discount promotions such as "buy one, get one free" that make cigarettes more affordable to kids, and free gifts such as mini-radios that appeal primarily to kids.

Given Philip Morris's marketing dominance and the continuing lure of the Marlboro Man, it's no wonder that more youth smokers in the USA-54.8\% - prefer Marlboro than all other brands combined. ${ }^{8}$

\section{STILL FIGHTING EFFECTIVE TOBACCO PREVENTION AND CONTROL}

But what about its highly touted youth prevention programmes. A recent study ${ }^{9}$ found that Philip Morris's "Think Don't Smoke" ads are ineffective at discouraging youth smoking and may even undermine harder hitting messages such as those in the American Legacy Foundation's "truth" campaign. The research found that non-smoking adolescents exposed to Philip Morris' ads were more likely to say they intend to smoke in the future.

Similarly, Philip Morris in April wrote to the state of Florida, which has one of the most successful tobacco prevention programmes in the USA, and asked that it stop running some of its ads. ${ }^{10}$ The contrast between Philip Morris's ads and Florida's ads could not be sharper. While the Philip Morris ads offer no reasons not to smoke, Florida's hard hitting, fact based ads expose the truth about the health effects of tobacco products and industry practices. Again, Philip Morris is offering a sham solution, while opposing what really works.

Philip Morris also continues to fight effective tobacco control measures across the USA, often funding front groups so it can remain behind the 
scenes. In Florida, Philip Morris was recently exposed as the sole funder of a group, called the Committee for Responsible Solutions, that sought to defeat a ballot measure to ban smoking in indoor public places. ${ }^{11}{ }^{12}$ Philip Morris took a similar approach in Washington state last year in an unsuccessful effort to defeat a cigarette tax increase that voters overwhelmingly approved. A Philip Morris employee served as the secret ghostwriter for materials distributed in opposition to the initiative by groups such as the Korean American Grocers Association. ${ }^{13}$

These tactics come from the same playbook as Philip Morris's infamous report in the Czech Republic, which sought to defeat tobacco control measures by arguing that early deaths from smoking save the government money in health care and benefits for the elderly. ${ }^{14}$ Almost lost in the subsequent outrage is the fact that this was not an isolated incident-Philip Morris was planning similar reports in Poland, Slovakia, Hungary, and Slovenia. ${ }^{15}$

Philip Morris's behaviour is at least consistent-in each of these examples, it sought to defeat or circumvent effective public health measures and only gave up when exposed and faced with a public relations nightmare. The moral of the story is that Philip Morris doesn't change unless it has no choice.

Renaming itself Altria is but the latest and most desperate of the company's self serving changes as it seeks to protect its political allies and its non-tobacco enterprises, such as the Kraft Foods, from the taint of its tobacco business.

To remind the American public of the real Philip Morris, the Campaign for Tobacco-Free Kids, the American Cancer Society, the American Heart Association, and the American Lung Association launched an advertising campaign to coincide with Philip Morris's 25 April 2002 shareholders meeting where the name change was approved (see cover).

Our ad reminded the public that while Philip Morris may be changing its name, it isn't changing its harmful practices. A snake that sheds its skin is still a snake.
To learn more about Philip Morris's recent activities and view a short animated film spoofing its name change, please visit a special part of our web site, www.PhilipMorrisCantHide.org.

\section{REFERENCES}

1 Alsop R. Harris Interactive survey indicates fragility of corporate reputations. Wall Street Journal, 8 February 2001.

2 US Federal Trade Commission. Cigarette Report for 2000 Washington DC: FTC, 2002. URL: http://www.ftc.gov/os/2002/05/ 2002cigrpt.pdf

3 King C, Siegel M. The Master Settlement Agreement with the tobacco industry and cigarette advertising in magazines. N Engl J Med 2001;345:504-11.

4 Bowker D, Hamilton M. Cigarette advertising expenditures before and after the Master Settlement Agreement: preliminary findings. 15 May 2000.

5 American Legacy Foundation. Tobacco brand magazine advertising to teens. Washington DC, American Legacy Foundation, 17 May 2000.

6 Rogers T, Fieghery E. Community mobilization to reduce point of purchase advertising of tobacco products. Health Educ $Q$ 1995;22:427-43

7 Anon. Study finds C-store promotions lacking. US Distribution Journal 1999;26:12

8 US Department of Health and Human Services, Substance Abuse and Mental Health Services Administration. Summary findings from the 2000 national household survey on drug abuse. Washington DC: USDHHS, 2001. URL: www.samhsa.gov/oas/nhsda.htm.

9 Farrelly M, Healton CG, Davis KC, et al. Getting to the truth: evaluating national tobacco countermarketing campaigns. Am J Public Health 2002;92:901-7.

10 Farrington B. Philip Morris asks Florida to pull anti-smoking ads. Associated Press, 12 April 2002.

11 Kennedy J. Group drops pro-tobacco ballot. Orlando Sentinel, 17 April 2002.

12 James J. Drive to maintain smoking rights collapses. Miami Herald, 17 April 2002

13 Connelly J. In the northwest: smoking out big tobacco's strategy to win votes. Seattle Post-Intelligencer, 31 August 2001

14 Fairclough G. Philip Morris notes cigarettes' benefits for nation's finances - analysis says Czech Republic saves billions of koruna because smokers die early. Wall Street Journal, 16 August 2001

15 Fairclough G. Philip Morris apologizes for report touting benefits of smokers' deaths. Wall Street Journal, 16 July 2001.
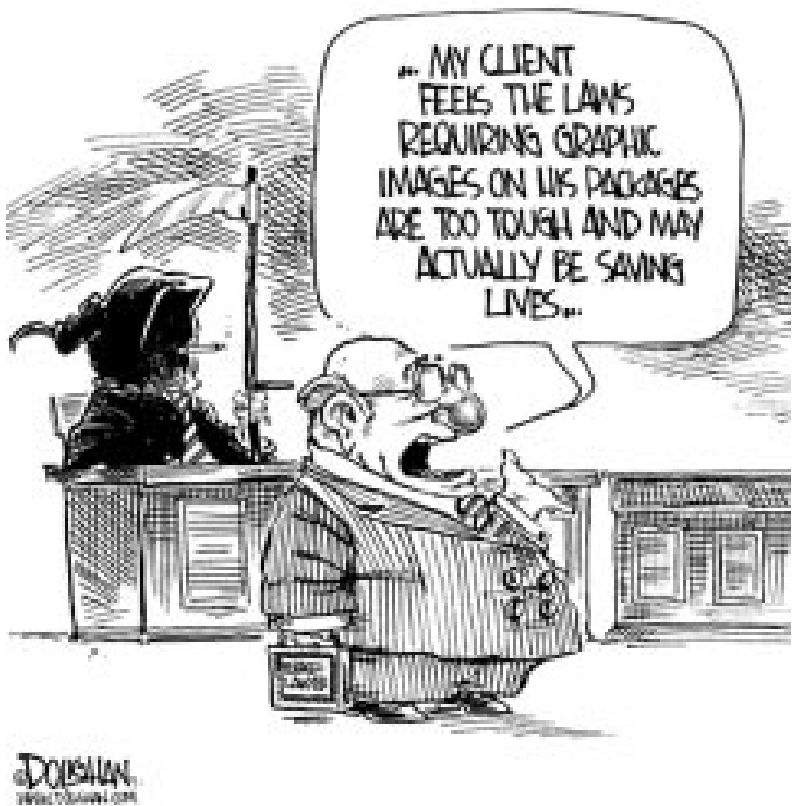

Canadian tobacco manufacturers go to court to challenge the legality of the government mandated, full colour warning labels that cover $50 \%$ of the front and back panels of cigarette packs. The companies are also charging that sections of the Tobacco Act dealing with advertising and sponsorship constitute unfair restrictions on "freedom of speech". (c) 2002 Tim Dolighan. All rights reserved. 